\title{
EGYPT'S WATER SECURITY SITUATION IN THE CONTEXT OF ASIA WATER DEVELOPMENT OUTLOOK APPROACH
}

\author{
Rabab Gaber*, and M. Nour El-Din \\ Irrigation and Hydraulic Department, Faculty of Engineering, Ain Shams University, Cairo, Egypt \\ *Corresponding Author E-mail: rabab1403@hotmail.com
}

\begin{abstract}
Water Security is very urgent for sustainable development in Egypt. Growing population needs more food production, water for drinking, hygiene, and to respond to economic activities which rely on access to more water. Worldwide, Water Poverty Index was used to express the water sector status and challenges. However, this index does not adequately represent the water sector status since its calculation is only based on available water resources and population. The scarcity index does not reflect the demand, the degree of water availability, efficiency, vulnerability, reuse, and water quality. To overcome such situation, the Asian Water Development Outlook (AWDO) was developed to investigate the actual water security status and its impact on the socio-economic and environmental development. The presented framework for assessment of Water Security comprises five Key Dimensions: (i) household water security, (ii) economic water security, (iii) urban water security, (iv) environmental water security, and (v) resilience to waterrelated disasters. According to the AWDO Methodology, Assessing Water Security in five dimensions will represent more accurately the inherent tension among water uses that emerge as water resources come under increasing stress. It may also be used to measure the outcome of integrated water resources management. In this paper the AWDO will be applied to assess the Water Security status in Egypt, evaluate its applicability, and recommend the necessary modifications added and removed parameters to suit the Egyptian local conditions.
\end{abstract}

Keywords: Water Security Index, Water Resources, Egypt, World, AWDO.

$$
\begin{aligned}
& \text { وضع الأمن المائى فى مصر فى ضوء منهجية آفاق تنمية المياه الاسيوية } \\
& \text { رباب جابر*، ومحمد نور الدين }
\end{aligned}
$$

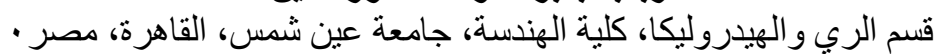

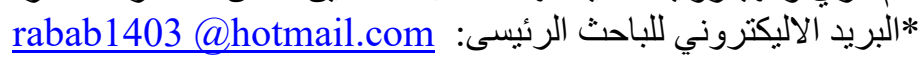

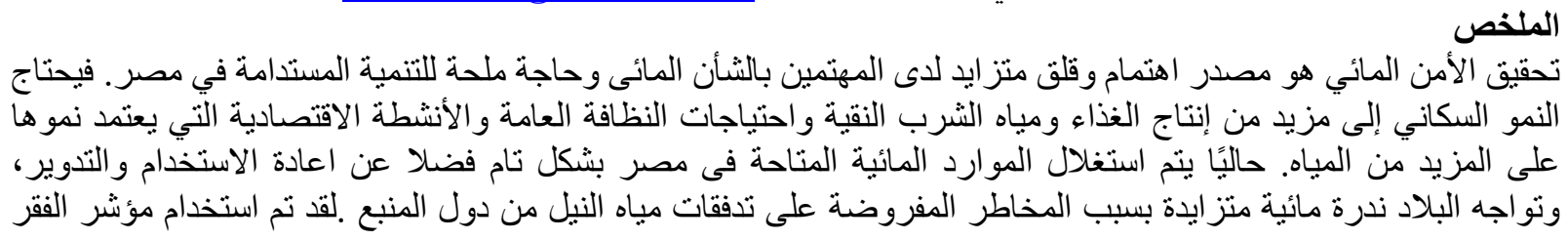




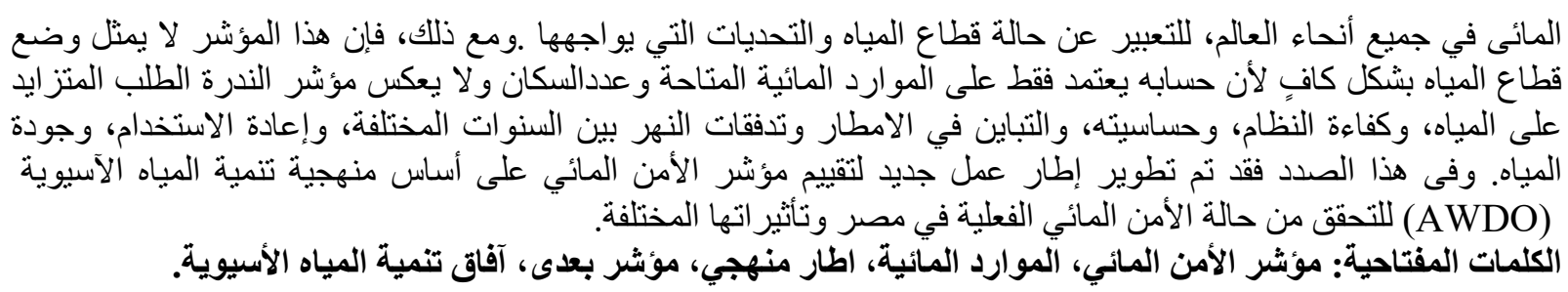

\section{INTRODUCTION}

Nowadays, Water Security is a very important concept since water became a prerequisite for all socio-economic development. The water security concept provides politicians, business leaders, water professionals, and many different disciplines and interest groups with a common language. It is a starting point for negotiating the complexities of allocating limited water resources among many competing and often conflicting demands.

Due to its importance, there are many definitions for water security, however; (Grey, D. and Sadoff, C., 2007) offered the most widely accepted definition: "The availability of an acceptable quantity and quality of water for health, livelihoods, ecosystems, and production, coupled with an acceptable level of water-related risks to people, environments, and economies".

To more accurately assess Water Security at both national and global levels and to facilitate comparing Water security status among countries, the ADB proposed the Water Security Index (WSI), which is linked to the socio-economic development.

Egypt is currently over-exploiting its water resources and is facing growing water scarcity mainly due to the increasing population, water quality deterioration with the impact of climate change, and development in Upper Nile countries without enough coordination with Egypt. These necessities precise assessment of Water Security and define the impact of IWRM interventions on the Water system. It is very important to have a tool, which we can use to assess water security. Water security index is recognized and used amongst others by different organizations as UN, ADB, World Bank, World Economic Forum, GWP, IUCN, OECD, IWMI, and UNESCO-IHP. The main two approaches in assessing the Water security index are the Overseas Development Institute (ODI) in the UK, which identified five keys for water security framework: Availability, Risk and variability, Equity, Ecosystems and biodiversity and Institutions and actors (Mason \& Clow26, 2012). The second approach is the Asian Water Development Outlook 2013 (AWDO, 2013) which outcome-based approach transforms the comprehensive vision of water security into a quantitative assessment consisting of five key dimensions. It assumes that societies enjoy water security when they successfully manage their water resources and water services to Satisfy household water\& Sanitation, support productive agriculture and industry, develop vibrant, livable cities and towns, restore healthy rivers and ecosystems, build resilient communities that can adapt to change. The Asian Water Development Outlook method provides the best applicable framework for the Egyptian circumstances.

In this paper, the AWDO will be applied to assess the Water Security status in Egypt, evaluate its applicability, and recommend the necessary modifications to suit the local Egyptian conditions.

\section{WATER SECURITY INDEX CONCEPT}

The important element for sustainable development is still engaged with water resources such as economy, society and environment. The concept of water security was developed to investigate the actual situations of these basic water developments with socio-economic and environmental development. According to the "(Asian Development Outlook, 2016) ", The overall National Water Security of each country is assessed as the composite result of five key dimensions, measured on a scale of $1-5$ (Figure 1): 

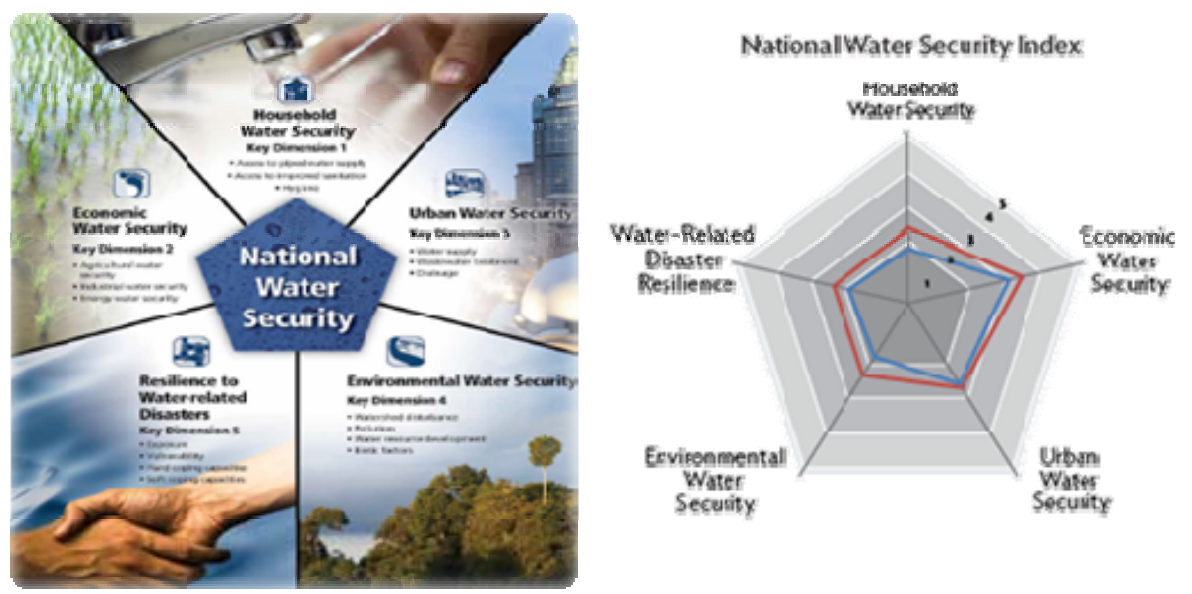

Figure 1: Water Security Index (After AWDO 2013)

\subsection{KD1 - HOUSEHOLD WATER SECURITY}

Household Water Security is essential for supporting economic and social development. As per Sustainable Development Goals (SDGs), SDG6, providing people with both safe water sanitation service, which are one of the SDGs Goals SDG6. KD1 It is composite of three indicators (i) access to a piped water supply (\%), (ii) access to improved sanitation (\%), and (iii) hygiene (age standardized DALYs per 100,000 people for the incidence of diarrhoea).

Improved sanitation facilities are those designed to hygienically separate excreta from human contact. There are three main ways to meet the criteria for having a safely managed sanitation service (SDG 6.2). People should use improved sanitation facilities, which aren't shared with other households, and the excreta produced should either be:

- Treated and disposed in situ,

- Stored temporarily and then emptied and transported to treatment off-site, or

- Transported through a sewer with wastewater and then treated off-site.

\subsection{KD2 - ECONOMIC WATER SECURITY INDEX}

The Economic Water Security Index measures how countries are ensuring the productive use of water to be sure that their economic growth in Agriculture production, industry, and energy will sustain. The International Water Management Institute (IWMI) and FAO were involved in developing indicators for each of the three sectors, using three main indicators that characterize water security including water for agriculture, water for industry and water for Energy. 
EGYPT'S WATER SECURITY SITUATION

IN THE CONTEXT OF ASIA WATER DEVELOPMENT OUTLOOK APPROACH

Table 1 Asian Water Development Outlook Framework Assessing National Water Security) Source: (Asian Development Outlook, 2016)

\begin{tabular}{|c|c|c|c|}
\hline Key Dimension & Index & What the Index Measures & What the Index is Composed of \\
\hline National Water Security & $\begin{array}{l}\text { National } \\
\text { water security }\end{array}$ & $\begin{array}{l}\text { How far countries have progressed } \\
\text { toward national water security }\end{array}$ & $\begin{array}{l}\text { Combination of the five dimensions } \\
\text { of water security measured by the key } \\
\text { dimensions }\end{array}$ \\
\hline Key Dimension 1 (KD1) & $\begin{array}{l}\text { Household } \\
\text { water security }\end{array}$ & $\begin{array}{l}\text { To what extent countries are } \\
\text { satisfying their household water } \\
\text { and sanitation needs and improving } \\
\text { hygiene for public health }\end{array}$ & $\begin{array}{l}\text { - Access to piped water supply } \\
\text { - Access to improved sanitation } \\
\text { - Hygiene index (measured in } \\
\text { disability-adjusted life years, DALYs) }\end{array}$ \\
\hline Key Dimension 2 (KD2) & $\begin{array}{l}\text { Economic } \\
\text { water security }\end{array}$ & $\begin{array}{l}\text { The productive use of water to } \\
\text { sustain economic growth in food } \\
\text { production, industry, and energy }\end{array}$ & $\begin{array}{l}\text { - Broad economic development } \\
\text { - Water for agriculture } \\
\text { - Water for industry } \\
\text { - Water for energy }\end{array}$ \\
\hline Key Dimension 3 (KD3) & $\begin{array}{l}\text { Urban water } \\
\text { security }\end{array}$ & $\begin{array}{l}\text { Progress toward better urban water } \\
\text { services and management to develop } \\
\text { vibrant, livable cities and towns }\end{array}$ & $\begin{array}{l}\text { - Urban water supply } \\
\text { - Urban wastewater collection } \\
\text { - Flood and storm drainage } \\
\text { - Urban river health }\end{array}$ \\
\hline Key Dimension 4 (KD4) & $\begin{array}{l}\text { Environmental } \\
\text { water security }\end{array}$ & $\begin{array}{l}\text { How well river basins are being } \\
\text { managed to sustain ecosystem } \\
\text { services }\end{array}$ & $\begin{array}{l}\text { - River health } \\
\text { - Flow alteration } \\
\text { - Environmental governance }\end{array}$ \\
\hline Key Dimension 5 (KD5) & $\begin{array}{l}\text { Resilience to } \\
\text { water-related } \\
\text { disasters }\end{array}$ & $\begin{array}{l}\text { The capacity to cope with and } \\
\text { recover from the impacts of water- } \\
\text { related disasters }\end{array}$ & $\begin{array}{l}\text { - Floods and windstorms } \\
\text { - Droughts } \\
\text { - Storm surges and coastal floods }\end{array}$ \\
\hline
\end{tabular}

\subsection{KD3 - URBAN WATER SECURITY INDEX}

The Urban Water Security Index measures the better water management to Support Livable water-sensitive cities. The Urban water Security index is composed of three indicators (a) Urban water supply (\%), (b) Wastewater treated (\%), (c) drainage, and (d) Adjustment factors for urban growth rate and river health. In fact, as cities pursue increasing states of sustainability a paradigm shift is required from managing waterways as a source of water to managing waterways for future generations. In Egypt more than $90 \%$ of the population currently lives in urban areas, that is make it an important driver of the economy.

\subsection{KD4 - ENVIRONMENTAL WATER SECURITY}

Rivers provide multiple goods and services that support human activities. Right now, many rivers are suffering from pollution, diminished flows, watershed deterioration, and increasing populations and industrial activities. The river Nile is one of these rivers which have highly pollution percentage because of the human activities and behaviors.

The Environmental Water Security Index assesses the river health and measures progress on restoring river and ecosystem to health on a national and regional scale. The analysis of the river health index (RHI) is based on the 2010 study (C. Vörösmarty, D. Lettenmaier, C. L, 2008) of biodiversity threats (BD threats) to rivers, a total of 23 input drivers relevant to $\mathrm{BD}$ threat analysis are organized into four themes - watershed disturbance, pollution, water resource management, and biotic factors.

\subsection{KD5 - RESILIENCE TO WATER-RELATED HAZARDS}

There is a global consensus on the importance of water-related risk management. Management requires quantification of water-related disaster analysis, AWDO 2013, the indicators of resilience to water-related disasters (KD5) use measures the level of hazard, exposure, 
EGYPT'S WATER SECURITY SITUATION

IN THE CONTEXT OF ASIA WATER DEVELOPMENT OUTLOOK APPROACH

vulnerability, and coping capacity to estimate the resilience index. The National Water-related Disaster index based on type of hazard (floods/windstorms, drought, and storm surges/coastal floods).

\section{ASSESSMENT OF WATER SECURITY INDEX FOR EGYPT}

(AWDO, 2013), and (ADB, 2013) provide a baseline for the analysis of trends and the impact of policies and reforms that can be monitored and reported to stakeholders through future AWDO editions. Water Security challenge in Egypt as one of the Middle East and North Africa region, which is the world's most water-stressed region is very great and in addition to that, newer challenges (complexities of the water-food-energy Nexus, climate change, droughts and floods, water quality, ....) are adding both hazards and complexity. Integrated Water Resources Management (IWRM) is very important, which matching between water resources and water demand is the target which Egypt looking for to secure water services.

Water scarcity term is not enough right now. Measuring water security, which takes into consideration the socio-economic impacts as well as water quality and many other aspects provide planners with new ways to manage water resources taking into consideration the weakness and strength. In the following section, the water security index for Egypt shall be calculated based on the AWDO 2013 methodology.

\section{KD1 - Household Water Security}

To calculate the household water security for Egypt, the data are categorized on a five-point scale, corresponding to progressively improving security in each sub-indicator, as shown in Table 2, the Household Water Index (KD1) for Egypt is amounted to 4.0.

Table 2: Calculation of KD1 - Household Security Index

\begin{tabular}{|l|l|l|}
\hline Indicator & Value & Score \\
\hline a. Access to piped water supply ${ }^{1}$ & $98.4 \%$ & 5 \\
\hline b. Access to safe sanitation ${ }^{1}$ & $93.0 \%$ & 4 \\
\hline c. Age standardized DALY per 100000 Diarrhea disease ${ }^{2}$ & 454 & 2 \\
\hline Total KD1 (a + b c, Maximum of 15) & & 11 \\
\hline KD1 (normalized to 20, then divided by 4-Maximum is 5) & 4 \\
\hline${ }^{1}$ Holding Company for Drinking Water and Sanitation, 2017 & \\
${ }^{2}$ Global Health Estimates 2016, Disease Burden By Cause Data & \\
\hline
\end{tabular}

\section{KD2 - Economic Water Security Index}

\section{$\underline{\text { Water for Agriculture }}$}

As mentioned earlier, Water for Agriculture indicator comprises three indicators. Calculation methodology and score for each indicator is as follow:

- Agriculture Resilience: it is calculated based on the intra variability of rainfall, which was estimated based on the temporal and spatial variability of annual and seasonal rainfall over Ethiopia (Wagesho, N. et al., 2013), while inter annual rainfall indicator was estimated based on the World Bank variability-tool ( http://iridl.ldeo.columbia.edu).

- Agricultural dependency: it is calculated based on the mean annual renewable storage, external renewable water resources, reservoir live storage, and agricultural water use data ("Agricultural virtual water, and industrial virtual water were based on Egypt Water Footprint (an indicator of Water and Food security (Sallam, O. 2013)"). 
- Agricultural use efficiency: it was calculated based on: (i) agricultural water productivity which is estimated based on the GDP report (MOP, 2018), and (ii) agricultural irrigated land, and arable land which were estimated based on Sustainable Agricultural development strategy towards 2030 (MALR, 2009).

Table 3: Calculation of Water for Agriculture indicator

\begin{tabular}{|l|l|}
\hline Indicator & Score \\
\hline Agricultural resilience & 5.3 \\
\hline Agricultural dependency & 3.0 \\
\hline Agricultural use efficiency & 9.0 \\
\hline Water for Agriculture sub-indicator (out of 10) & 5.78 \\
\hline
\end{tabular}

\section{Water for Industry}

- Industrial water productivity: it is calculated by dividing the financial value generated for industrial goods in Egypt by the amount of water withdrawn for industry.

- Industrial footprint: it is calculated by dividing the quantity of water used to produce industrial goods consumed by the amount of water withdrawn for industry.

- For both indicators, a five point scale was applied; a value of 5 for the countries which their production is close to their consumption, and a value of 1 for countries which depend heavily on import. Table 4 shows the results of Industrial Water indicator.

\section{Table 4: Calculation of Water for Industry indicator}

\begin{tabular}{l|l}
\hline Sub-Indicator & Score \\
\hline Industrial water productivity $^{1}$ & 3.5 \\
\hline Industrial footprint ${ }^{2}$ & 1.5 \\
\hline Water for Industry sub-indicator (out of 10) & 5.0 \\
${ }^{1}$ Financial industrial value data based on GDP report (MOP, 2018). Industrial water consumptive use was estimated \\
based on NWRP - Water Balance (2018). \\
${ }^{2}$ Industrial footprints is estimated based on Egypt Water Footprint (an indicator of Water and Food security (Osama \\
M. Sallam, 2013)
\end{tabular}

\section{Water for Energy}

- Proportion of technically exploitable hydropower capability that has been tapped: it is calculated by dividing the amount of currently generated electricity by the technically exploitable potential. On a five-point scale, where five indicates low percent tapped and 1 indicates high percent.

- The relative contribution of hydropower to energy supply: it was calculated by dividing the generated hydropower to the total generated energy. On a five-point classification scale, 5 for higher contributions of hydropower to overall energy supply, to 1 for a lower contribution. 
EGYPT'S WATER SECURITY SITUATION

IN THE CONTEXT OF ASIA WATER DEVELOPMENT OUTLOOK APPROACH

Table 5: Calculation of Water for Energy indicator

\begin{tabular}{l|l|}
\hline Indicator & Score \\
\hline $\begin{array}{l}\text { Proportion of technically exploitable hydropower capability that has been tapped }{ }^{1} \text { (out of 5) } \\
\text { The relative contribution of hydropower to energy supply (out of 5) }\end{array}$ & 1.0 \\
\hline $\begin{array}{l}\text { Water for Energy sub-indicator (out of 10) } \\
{ }^{1} \text { Generated hydropower, potential hydropower, total generated electrical power are calculated based on the annual } \\
\text { report of the Holding company for Electricity } 2017 .\end{array}$ & 3.0 \\
\hline
\end{tabular}

Table 6 shows the results for each economic sector. The Overall Economic Water Security Index (Agriculture, Industry, and Energy) is the total of the three main contributing activities where normalized to have full value of 5 . The normalized mean of the scores for each sub-index gives the total economic water security of the country's economy. The average of indicators produces a value of KD2 equals 2.29.

Table 6: Overall Economic Water Security Index

\begin{tabular}{|l|l|}
\hline Indicator & Score \\
\hline Water for Agriculture & 5.78 \\
\hline Water for Industry & 5.0 \\
\hline Water for Energy & 3.0 \\
\hline Overall Water Security Index & 2.29
\end{tabular}

\section{KD3 - Urban Water Security Index}

As Egypt gives high priority to cover $100 \%$ of urban areas with safe drinking water, the related indicator got score of 5 . On the other hand, efforts to cover urban areas with wastewater treatment still is going, thus the related indicator got 2.6 out of 5. Urban flood damage was estimated based on flash flood hazard affected Red Sea areas. The damage was estimated at $0.4 \%$ of the Gross Domestic Product and score 4.3 out of 5 . The sum of the three sub-indicators is corrected for urbanization factor and urban river management factor. Based on the data and calculations presented in Table 7, the Urban Water Security Index for Egypt scores 2.0.

Table 7: Urban Water Security Index

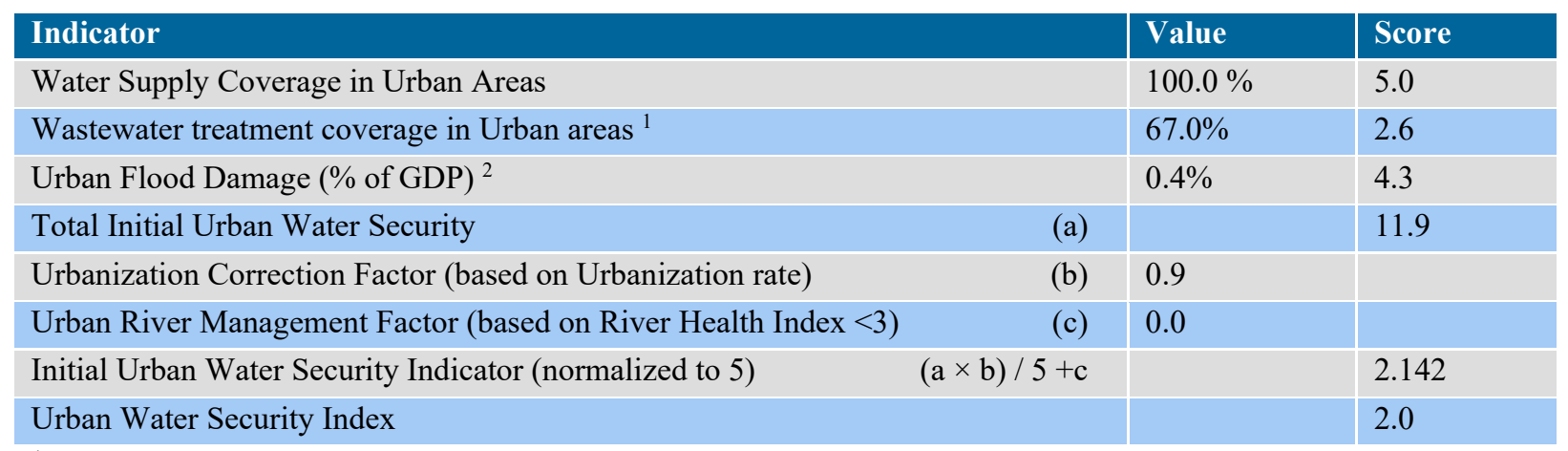

${ }^{1}$ UN-Water and WHO, 2018, and Egypt Water Sector M\&E Rapid Assessment Report (CEDARI, Egypt Water Sector M\&E Rapid Assessment Report Mewina , 2014)

2 (Water Resources Management Institute, 2017) 
EGYPT'S WATER SECURITY SITUATION

IN THE CONTEXT OF ASIA WATER DEVELOPMENT OUTLOOK APPROACH

\section{KD4 - Environmental Water Security Index}

Calculating Environmental Water Security Index is based on river health basin and includes four themes that in turn include 23 drivers. These drivers represent most of the parameters related to environment. Table 8 includes the calculations of the KD 4 index for the year 2017 which scores 2.0 .

Table 8: Environmental Water Security Index

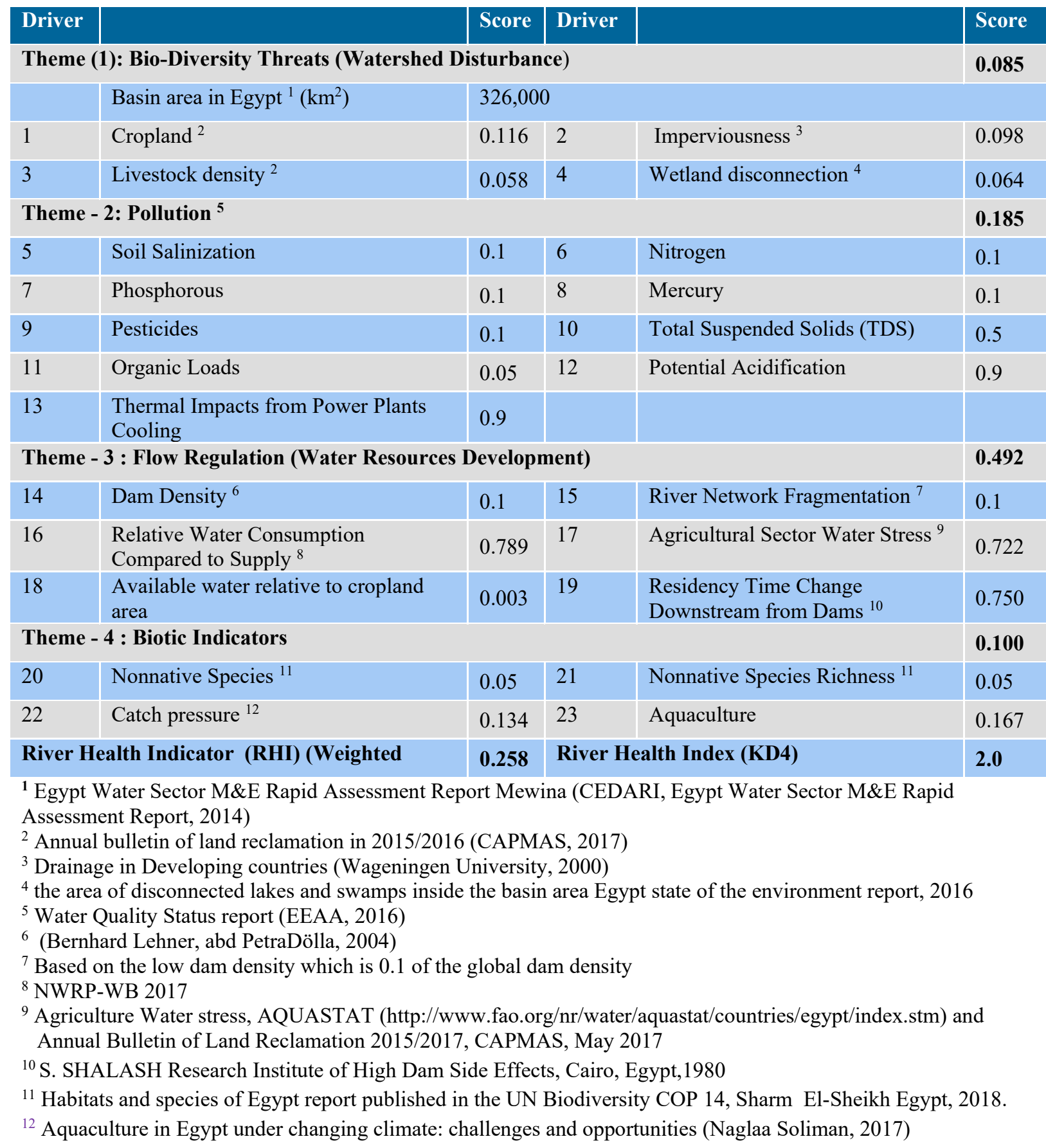




\section{KD5 - Resilience to Water-Related Hazards Index}

The calculation of the Resilience to Water Related Hazard Index comprises three categories: flood resilience, drought resilience, and storm surge coastal flooding resilience. Each category is evaluated against five sub drivers: hazards, exposure, vulnerability, hard coping index and soft coping index. The total resilience index is calculated by summing up the three categories. As shown in Table 9, the Resilience to Water Related Hazards Index for Egypt is 2.0. Detailed calculation of each driver is given in Table 10.

Table 9: Resilience to Water-Related Hazards Index (KD 5)

\begin{tabular}{|l|l|}
\hline Indicator & Score \\
\hline Flood Resilience & 0.3428 \\
\hline Drought Resilience & 0.319 \\
\hline Storm Surge Coastal Flooding Resilience & 0.324 \\
\hline Total Resilience Indicator (sum of 3 sub indicators) & 0.9863 \\
\hline Total Resilience Index KD 5 & $\mathbf{2 . 0 0}$ \\
\hline
\end{tabular}

\section{Overall Water Security Index (WSI)}

According to the AWDO methodology, the Water Security Index (WSI) for Egypt scores 2.46. According to the AWDO, this means that the water system in Egypt is classified as between capable and engaged. 
EGYPT'S WATER SECURITY SITUATION

IN THE CONTEXT OF ASIA WATER DEVELOPMENT OUTLOOK APPROACH

Table 10: Detailed calculation of Resilience to Water-Related Hazards Index(KD 5)

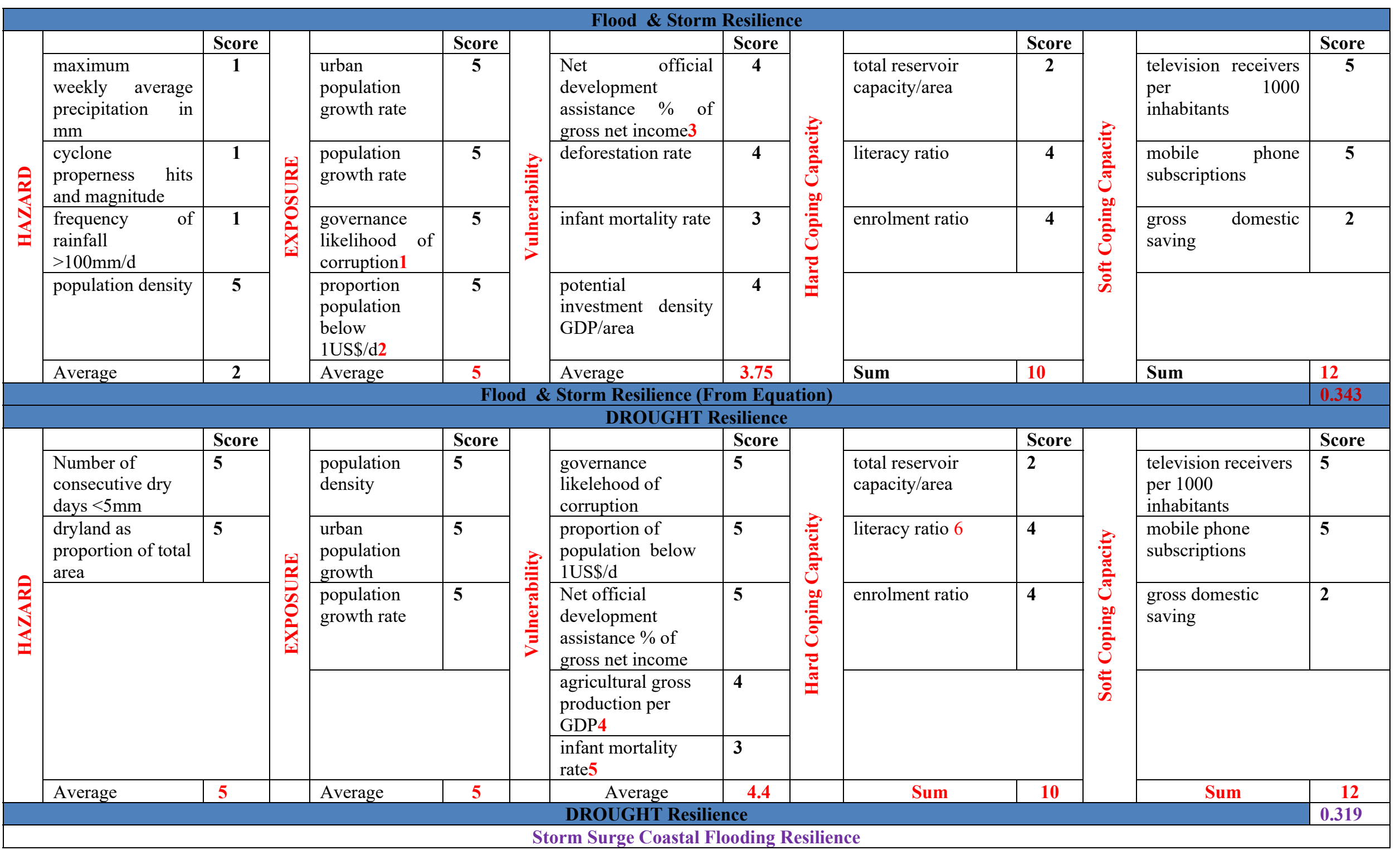


EGYPT'S WATER SECURITY SITUATION

IN THE CONTEXT OF ASIA WATER DEVELOPMENT OUTLOOK APPROACH

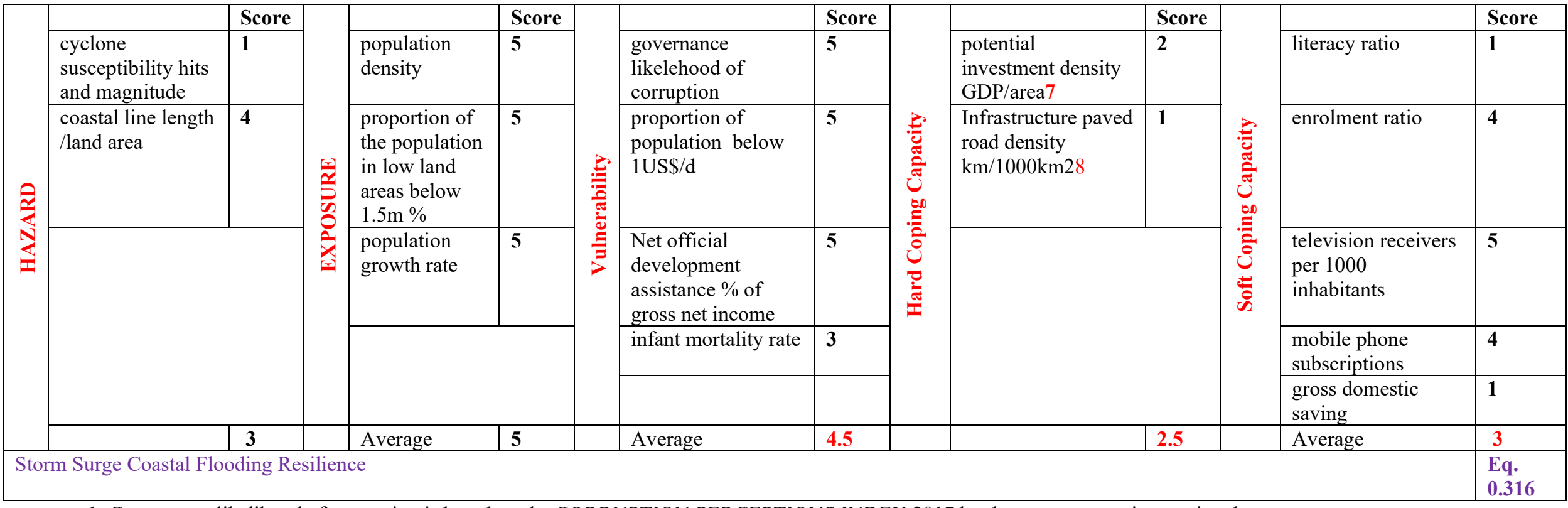

1. Governance likelihood of corruption is based on the CORRUPTION PERCEPTIONS INDEX 2017 by the transparency international org.

2. Proportion of population below 1 US\$/d is based on CAPMAS household income, 2016

3. Net official development assistance and official aid received (current US\$) in Egypt was reported at 2.13 billion USD in 2016, according to the World Bank collection of development indicators, compiled from officially recognized sources. This represents $4.3 \%$ of gross net income

https://tradingeconomics.com/egypt/net-official-development-assistance-and-official-aid-received-us-dollar-wb-data.html

4. Agricultural gross production per GDP is $11 \%$ according to the MOP gross domestic products report in 2016

5. Infant mortality rate is based on the WHO burden disease statistics report 2016

6. Literacy ratio, the enrolment ratio, urban population growth are based on the Human development report UNDP,2018,

http://hdr.undp.org/en/countries/profiles/EGY

7. Potential investment density GDP/area

8. Infrastructure paved road density is $137,430 \mathrm{~km}$, which equal to $137 / 1000 \mathrm{~km}^{2}$ is based on:

https://en.wikipedia.org/wiki/List of countries by road network size\#cite note-27 
Egypt's Water Security Situation in the context of Asia Water Development Outlook Approach

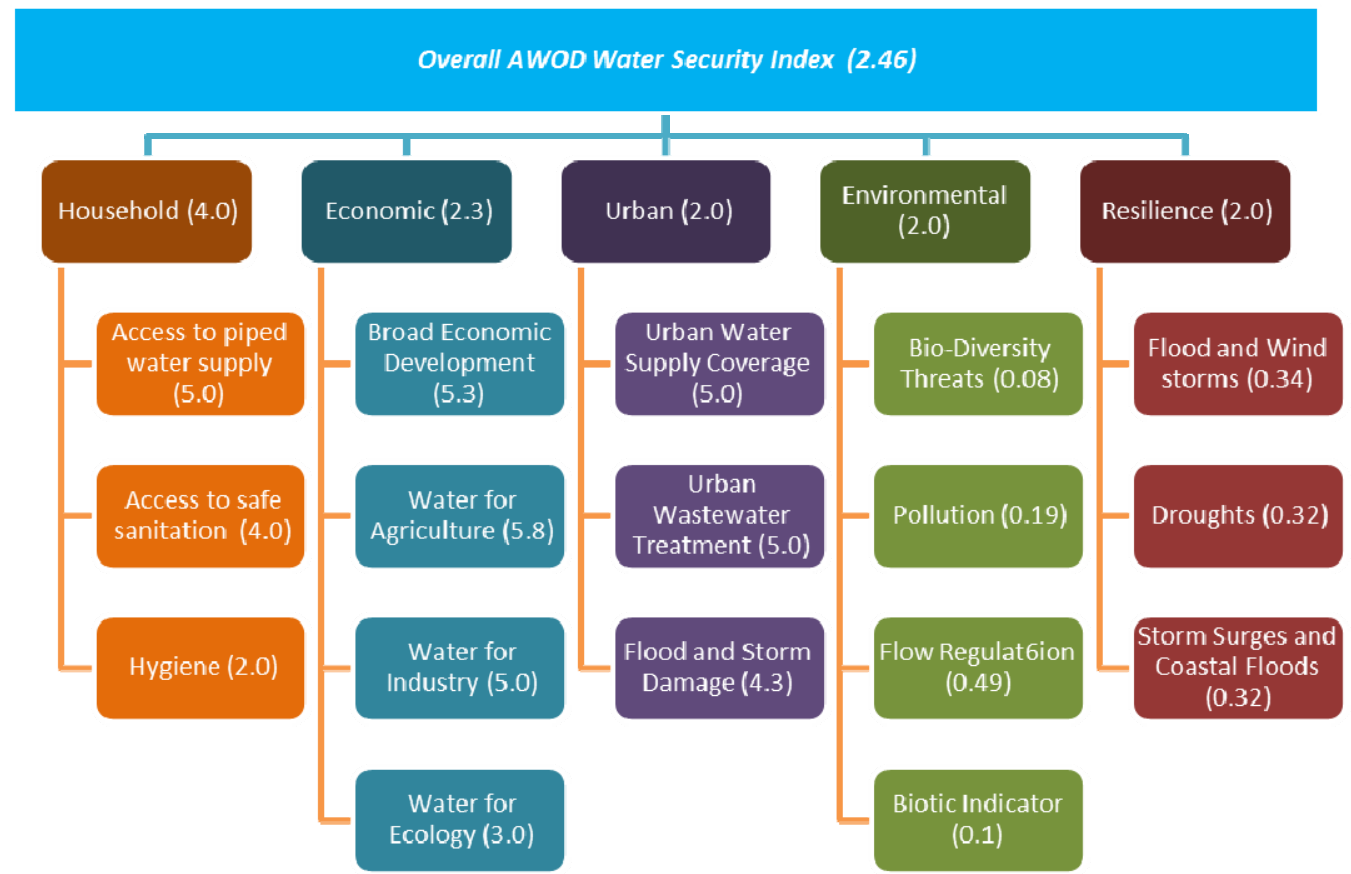

Figure 2: Water Security Index for Egypt (AWOD)

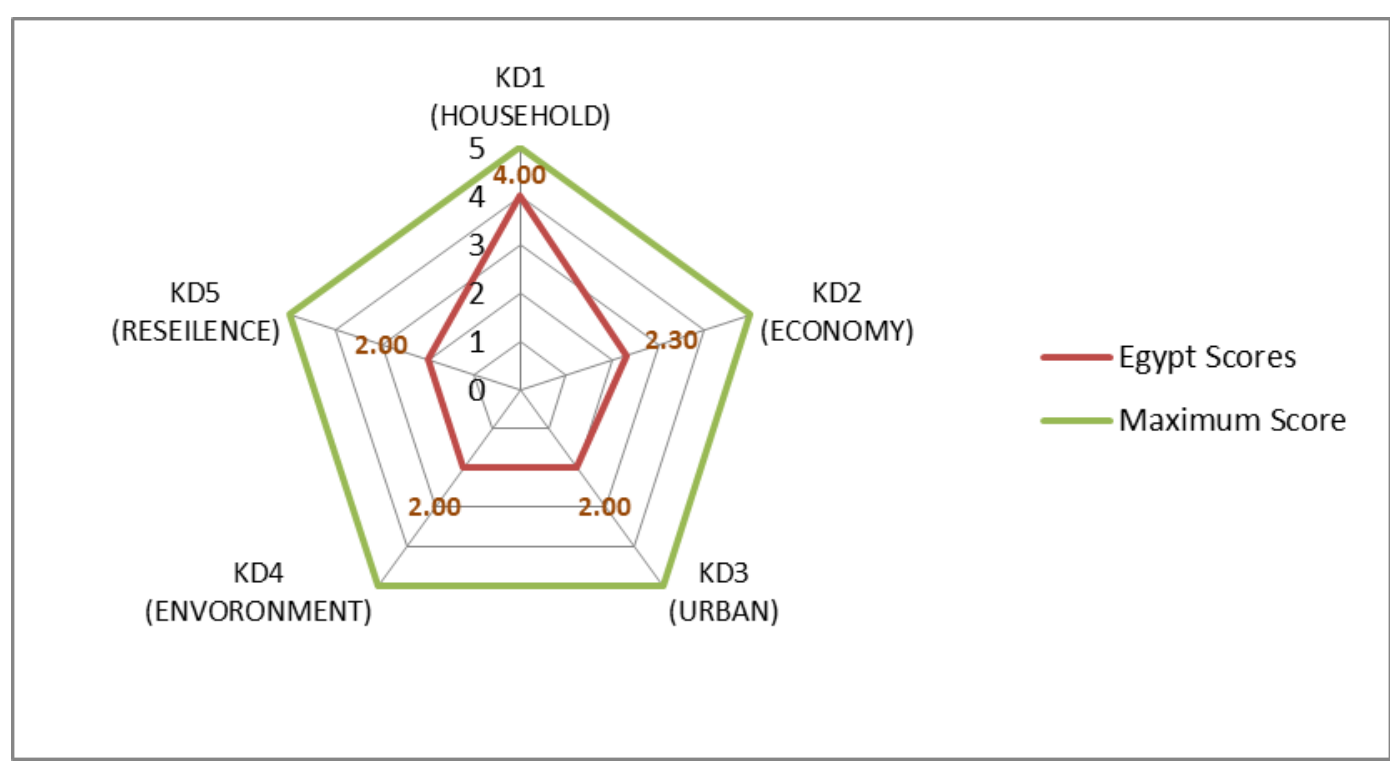

Figure 3: Diamond shape representation of the water security index of Egypt

\section{ANALYSIS AND DISCUSSIONS}

- Household Water Security Key Dimension (KD 1) scores 4 out of 5 which means that KD1 is almost secured. However, DALY index still needs to be improved to reduce Diarrhea. This can be achieved through implementing measures to protect public health such as launch public awareness campaign, allow sufficient finance to protect public health, reducing the access to polluted water in rural area.

- Economic Water Security Key Dimension (KD 2) scores 2.29 that means the situation is near to insecure. The index could be improved by enhancing agricultural efficiency and Productivity through raising water conveyance and distribution efficiencies of the 
irrigation system. This could be achieved by applying canal lining, applying continues flow regime, improving mesqas with single point lifting, and through increase investments to improve / rehabilitate the old irrigation structures.

- Applying modern irrigation technologies, provide extensive extension services, and replace high water consumptive crops by high value crops will have positive impact on the KD 2 index.

- Improve Industrial water use efficiency through applying modern cooling systems, improve housekeeping, and circulating cooling water will improve the KD 2 index score.

- KD2 does not consider neither the per capita renewable water resources indicator nor the water needs for aquaculture. Food security is also not represented in the index.

- Climate change will have negative impact on KD2 as the sea level rise may inundate some parts of the Northern Delta. The severity of climate change will determine the impact on the index. The government put high investments to protect the coastal areas, however, there is a need to take necessary mitigating measures to ensure the minimum possible damage to the coastal areas and consequently guarantee the index would not negatively influenced.

- Other factors that could affect WSI in general and KD 2 in particular include affordability, governance, political support, PPP, publicly accessible information, and utility ownership and leadership.

- Urban Water Security Key Dimension (KD 3) scores 2.0 that means the situation is near insecure. This is mainly due to the high flood damage risk and the relatively low wastewater treatment coverage. The Egyptian government currently put high investments to protect the cities vulnerable to flash flood in Red Sea and Sinai areas which is expected to enhance the index. Also, efforts to construct new wastewater treatment plants and upgrade the existing plants are ongoing. Both interventions will improve the index. Obviously, the higher investments in both interventions the better the score of the index.

- River health factor does not have impact of KD 2. It is recommended to exclude it in the calculations given it is the backbone of the calculations of Environmental Water Security KD 4.

- Environmental Water Security Key Dimension (KD 4) scores 2.0, that means the situation is near secure. This is mainly due to the high water shed disturbance due to the disconnection of the wetland and coastal lakes due to: (a) the urbanization, (b) construction of highways inside the lakes area, (c) sedimentation of the lakes, and (d) the lakes outlet to the Mediterranean Sea.

- Water Resources Development indicator in the watershed is low and the flow regulation is moderately affected by the High Aswan Dam and the main barrages on the Nile.

- The biotic factors indicator is low due to the high catch pressure on the fisheries and aquaculture.

- The pollution indicator represents the highly polluted watershed including the River Nile, canals, drains, and lakes.

- Calculation of the Environmental Water Security KD4 which is based on 23 biodiversity threats is complicated and may not be applicable for the Egyptian case where most of the land is desert areas. For better representation of the Egyptian case, the following modifications are proposed: 
- Subdividing the watershed into grids using GIS maps, where biodiversity indicators and threat levels can be quantified, and the discharge of the water shed can be calculated on a grid-cell scale.

- linking the environmental and human aspects of water security is highly recommended. This can be done by introducing the Human Development Index (HDI) and relate it with Environmental Water Security.

- It is recommended to investigate the applicability and suitability of using Water Quality Index which is more relevant to the Egyptian situation to calculate KD 4 instead of the current methodology.

- Resilience to Water-Related Hazards Key Dimension (KD 5) scores 2.0, that mean the situation is near insecure; this is mainly due to some dimension which is not applicable to Egypt.

- Not all the drivers of KD 5 are applicable for Egypt such as storm surge, and river flood. The index can better represent the Egyptian case by adding some hydro-politics such as:

- The transboundary dimension as more than 95\% from the Water Resources in Egypt is originated outside the country.

- The water storages and reserves for future

- Political stability and governance in the country

\section{CONCLUSION AND RECOMMENDATIONS}

The aim of this paper is to assess water security index for Egypt and to develop a more robust approach for assessing the water security index. The first step is to apply the AWDO approach to the Egyptian case, analyze and evaluate the results, and highlight the necessary recommendations to better represent the Water Security in Egypt.

The Five key components of AWDO Water Security Index were calculated for Egypt, the value of KD 1 scores 4.0, KD 2 scores 2.3 while KD3, KD 4, and KD 5 are all equal 2.0. The Overall WSI is 2.46 that means the water system is characterized as Capable and engaged.

The development and application of the approach described in the paper has helped to clarify the notion of water security and prompts a new framework for water security index estimation for reaching a more common understanding of the meaning and utility of the concept.

Water Security can be improved by applying certain interventions, for instance KD 1 can be improved by launching public awareness campaign, allow sufficient finance to protect public health, reducing the access to polluted water in rural area. KD2 can be improved by applying canal lining, applying continues flow regime, improving mesqas with single point lifting, applying modern irrigation technologies, provide extensive extension services, and replace high water consumptive crops by high value crops, applying modern cooling systems, improve housekeeping, and circulating cooling water. KD 3 and KD 4 can be improved by increase investments in water sector and reduce water pollution in the waterways.

AWDO as proposed by the ADB is very powerful tool to assess the water security in a country, however, for better representation of the system and to accurately calculate the Water Security Index, some modifications to the methodology are considered unavoidable. These include:

- Adding food security, per capita renewable water resources, and aquaculture indicators and remove River Health Factor impact to KD2.

- Study the applicability and suitability of replacement of Environmental Water Security Index by Water Quality Index. 
- Eliminate indicators that are not applicable to the Egyptian case in calculating KD 5, such as storm surge, and river flood. Items to be considered in calculating $\mathrm{KD} 5$ include transboundary dimension and the water storages and reserves for future.

- Moreover, it is proposed that the WSI would include additional indicators such as political stability, political support, governance, affordability, PPP, publicly accessible information, utility ownership and leadership and Human development index.

\section{REFERENCES}

[1] Asian Development Bank. (2016). Asian Development Outlook strengthening water security in asia and the pacific. Avenue, Mandaluyong City,1550 Metro Manila, PhilippinesTel +63 2632 4444; Fax +63 2636 2444: Asian Development Bank ADB, www.adb.org.

[2] AWDO. (2013). Asian Development Outlook. Asian Development Bank.

[3] Bernhard Lehner, abd PetraDölla. (2004). Development and validation of a global database of lakes, reservoirs and wetlands. Journal of Hydrology, Volume 296, Issues 1-4, 20 August 2004, Pages 1-22.

[4] C. Vörösmarty, D. Lettenmaier, C. L. (2008). Humans transforming the global water system. A Historical-Geographical Critique of a Modern Concept, Annals of the Association of American Geographers, 10.1080/00045600802046619, 98, 3, (630649), (2008).

[5] CAPMAS. (2017). Annual bulletin of land reclamation in 2015-2016 . Cairo: Central Agency for Public Mobilization and Statistics.

[6] Cedari. (2014). Egypt Water Sector M\&E Rapid Assessment Report Mewina . Cairo: cedari.

[7] EEAA. (2016). The area of disconnected lakes and swamps inside the basin area, Egypt state of the environment report, 2016. Cairo: EEAA.

[8] EEAA. (2018). Habitats and species of Egypt report . Sharm El-Sheikh Egypt: published in the UN Biodiversity COP 14.

[9] EEAA. (2018). Water Quality Status report . Cairo: EEAA.

[10] Grey, D. and Sadoff, C. . (2007). Grey, D. and Sadoff, C. (2007) Sink or Swim? Water Security for Growth and Development. . Water Policy, 9(6): 545-571. .

[11] Ministry of Agricultural and Land Reclamation. (2012). Agricultural Strategy of Egypt in 2030. Cairo: Ministry of Agricultural and Land Reclamation.

[12] Ministry of Planning. (2018). Gross Domestic Product estimation. Cairo: Ministry of Planning, Egypt.

[13] Ministry of water resources and irrigation. (2018). National Water Resource Strategy, and Plan 2030. Cairo: Ministry of water resources and irrigation.

[14] Naglaa Soliman. (2017). Aquaculture in Egypt under changing climate: challenges and opportunities. Alexandria, Egypt: Institute of Graduate Studies and Research (IGSR), Alexandria university.

[15] Negash Wagesho, N.K. Goel \& M.K. Jain. (2013). Temporal and spatial variability of annual andseasonal rainfall over Ethiopi. Hydrological Sciences Journal, , 58:2, 354373, DOI: 10.1080/02626667.2012.754543.

[16] Osama M. Sallam. (2013). Egypt Water Footprint (an indicator of Water and Food security).https://www.researchgate.net/publication/270106405_Egypt_Water_Footprin t_an_indicator_of_Water_and_Food_security. 
[17] S. SHALASH . (1980). The effect of the High Aswan Dam on the hydrological regime of the River Nile. (Proceedings of the Helsinki Symposium, June 1980; Actes du Colloque d'Helsinki, juin 1980): IAHS-AISHPubl.no. 130. (p. 130).

[18] Wageningen University. (2000). Drainage in Developing countries. Wageningen, Netherland: Wageningen University.

[19] Water Resources Management Institute. (2017). Urban Flood Damage in Egypt. Cairo: Water Resources Management Institute, NWRC.

[20] WHO. (2018). Global Wastewater Treatment Market Trends and Forecast 2018-2024. Genev, Switzerland: WHO. 